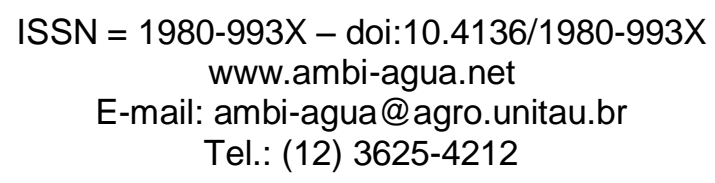

\title{
Groundwater chemistry of the Oban Massif, South-Eastern Nigeria
}

\author{
(http://dx.doi.org/10.4136/ambi-agua.812)
}

\author{
Azubuike S. Ekwere; Aniekan E. Edet; Solomon J. Ekwere \\ Department of Geology, University of Calabar, Calabar, Nigeria \\ e-mails: zerratta77@yahoo.com; aniekanedet@yahoo.com; \\ zerratta78@blackplanet.com
}

\begin{abstract}
Hydrogeochemical study of the fractured/weathered basement of the Oban Massif, southeastern Nigeria has been carried out. Results indicated that concentrations of major cations and anions exhibited the following order of abundance: $\mathrm{Ca}>\mathrm{Na}>\mathrm{Mg}>\mathrm{K}$ and $\mathrm{HCO}_{3}>\mathrm{SO}_{4}>\mathrm{Cl}$, respectively, with minor variations across sampling seasons. $\mathrm{Ca}-\mathrm{Na}-\mathrm{Cl}-\mathrm{SO}_{4}$ and $\mathrm{Ca}-\mathrm{Mg}-\mathrm{HCO}_{3}$ water types have been identified as major facies, resultant from congruent influences of weathering (mainly silicates), ion exchange processes, and water mixing.
\end{abstract}

Keywords: groundwater; cation; anion; weathering; ion exchange; Oban massif; Nigeria.

\section{Química das águas subterrâneas do Maciço Oban, Sudeste da Nigéria}

\section{RESUMO}

Estudo hidrogeoquímico do embasamento fraturado / intemperizado do Maciço Oban, sudeste da Nigéria foi realizado. Os resultados indicaram que as concentrações de cátions e ânions apresentaram a seguinte ordem de ocorrência: $\mathrm{Ca}>\mathrm{Na}>\mathrm{Mg}>\mathrm{K}$ e $\mathrm{HCO}>\mathrm{SO} 4>\mathrm{Cl}$, respectivamente, com pequenas variações entre as estações de amostragem. Os tipos de água $\mathrm{Ca}-\mathrm{Na}-\mathrm{Cl}-\mathrm{SO} 4$ e Ca-Mg-HCO3 têm sido identificados como os principais fácies, resultantes de influências congruentes de desgaste (principalmente silicatos), processos de permuta iónica e água de mistura.

Palavras-chave: água subterrânea; catiônica; ânion; intemperismo; troca iônica; Oban maciço; Nigéria.

\section{INTRODUCTION}

The ability to estimate the rate and extent of water-rock interaction and chemical transport depends on the quantitative understanding of the physical and chemical properties of the rocks and fluids participating in reactive transport properties in natural systems (Oelkers, 1996).

Composition of sub-surface waters in basement areas is a function of many variables, which include; composition of recharge water, petrologic and mineralogic composition of sub-surface rocks and hydrogeologic properties of the rocks, which influence water-rock reactions and groundwater flow velocities. According to Caritat et al. (2004), generally chemical quality of groundwater from basement bedrock is often very different from waters from superficial deposits. Bedrock groundwater is often more mature more basic, more 
reducing, and more sodium rich and contains more of most minor/trace elements than groundwater from shallow aquifers.

Variations in physical and chemical composition of basement groundwater may also be due to mixing with shallow groundwater from the overburden. Present increases of population with higher demands for water resources are typical in most developing Sub-Saharan countries. This has led to water scarcity and increasing water stress in most of these regions. Nigeria belongs to this equatorial region with most of its harnessed water resources being of surface and sub-surface origin.

The Oban Massif lies in the southeastern part of Nigeria and it is considered the most important groundwater reservoir in Cross River state (Nigeria), providing water to the various cottage industries and communities in the area. The rock types are mostly gneisses, granodiorites, and schist. Groundwater extraction is mainly through shallow wells and hand pump fitted boreholes and in some cases surface water.

Natural geochemical processes play an important role in groundwater quality. The aim of this work is to characterize the chemical processes occurring in the water-bearing horizon.

Previous studies in the area have been on the geology, petrology, and geochemical aspects of the massif. This study therefore forms the first ever study on the hydrochemical evolution of groundwater in the area.

\section{DESCRIPTION OF STUDY AREA}

The Oban Massif lies between Longitudes $8^{0} 00^{\prime} \mathrm{E}$ and $8^{0} 55^{\prime} \mathrm{E}$ and Latitudes $5^{0} 00^{\prime} \mathrm{N}$ and $5^{0} 45^{\prime} \mathrm{N}$ covering an area of about 8,740 square kilometers (Edet et al., 1998), Figure 1. The crystalline basement complex lies at an average height of about $150 \mathrm{~m}$, rising gradually from the south northwards and falls away towards the Cross River to the North (Ayi, 1987). Fractures and joints control drainage within the massif. The massif is well drained with a network of rivers and associated streams, actively engaged in erosion of channels (juvenile stage). The area is characterized by a tropical climate with two distinct seasons viz wet and dry. The wet season spans from May to October, while the dry season lasts from November to April. The average monthly temperature in the area ranges from $29-34^{0} \mathrm{C}$. Mean annual rainfall of about $2,300 \mathrm{~mm}$ have been reported for the area, with annual mean daily relative humidity and evaporation of $86 \%$ and $3.85 \mathrm{~mm} /$ day respectively (CRBDA, 2008).

The Oban Massif is described as being underlain by highly deformed Precambrian crystalline basement rocks, mainly migmatites, granites, gneisses, and schists (Ekwueme and Ekwere, 1989; Ekwere and Ekwueme, 1991). These rocks exhibit varying degrees of weathering across the massif. They are intruded by pegmatites, granodiorites, diorites, tonalites, monzonites, charnokites and dolerites (Ekwueme, 1990).

\section{MATERIALS AND METHODS}

Seventy-four water samples, covering both dry and wet seasons were collected. The dry season samples were collected in the month of February and those for the wet in the July of 2009. The sample locations straddled the various geologic units within the study area. The water samples were obtained from motorized and hand pump fitted boreholes, open wells, and stream channels.

Three samples were collected from each location in $75 \mathrm{cl}$ polyethylene bottles. The sample bottles were soaked in $10 \% \mathrm{HNO}_{3}$ for 24 hours and rinsed several times with deionized water prior to use. At the sampling locations, the bottles were thoroughly rinsed with aliquots of the sampled waters, prior to collection. 
One sample from each location was preserved by acidifying to $\mathrm{pH}$ ca. 2 with $0.5 \mathrm{ml}$ of concentrated $\mathrm{HNO}_{3}$ acid before analysis for trace metals. All samples were packaged (airtight), labeled and stored in coolers for onward transportation to the laboratory for analysis.

Measurements of temperature, conductivity, TDS, $\mathrm{pH}$, Eh were carried out in the field using standard field equipment (PHT-027 multi-parameter). Prior to measurement of $\mathrm{pH}$, the electrode was calibrated using $\mathrm{pH} 6.88$ and 4.01 buffer solutions at a similar temperature to the water samples. The same meter and an ionodes ORP electrode were used to measure Eh. Calcium, magnesium, sodium, and potassium contents were determined with reference to the APHA (1995) method. Major and trace element contents were determined by atomic absorption spectrophotometer (AAS), model UNICAM 939. The anion contents of samples were determined by colorimetric method using UNICAM UV2 spectrophotometer. All instrumental analyses were carried out in the laboratories of the Aluminum Smelting Company of Nigeria (ALSCON), Ikot Abasi, Nigeria.

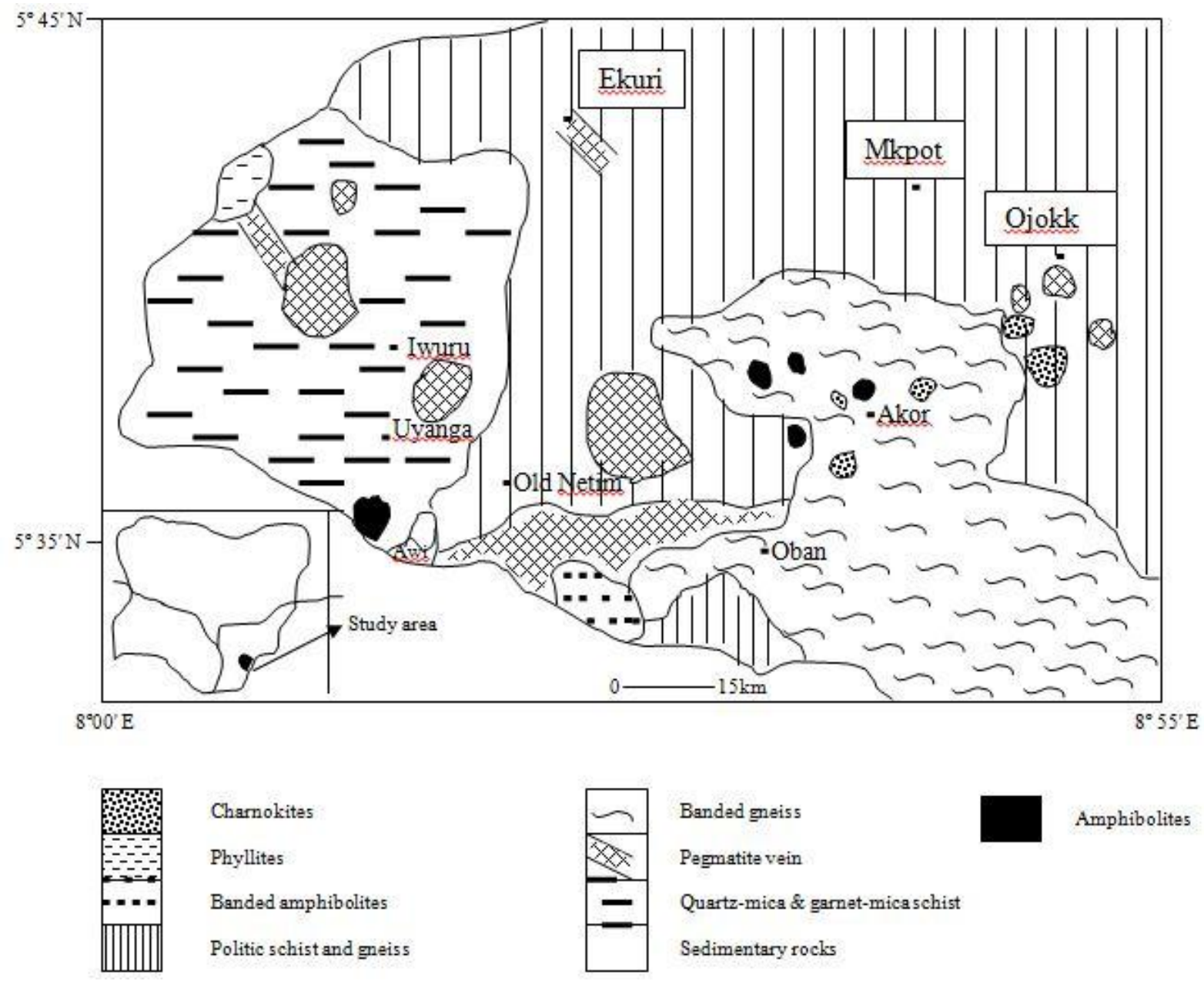

Figure 1. Geologic map of the study area (Oban massif): insert map of Nigeria (modified from Ekwueme, 2003). 


\section{RESULTS AND DISCUSSION}

Compositions of ground and surface waters in the wet and dry seasons within the Oban massif are given in Tables 1 and 2. Statistical summary shows the water is slightly acidicalkaline (5.08 - 8.65), fresh with total dissolved solids (TDS) $<1000 \mathrm{mg} / \mathrm{l}$.

The cations were in the order $\mathrm{Ca}^{2+}>\mathrm{Na}^{+}>\mathrm{Mg}^{2+}>\mathrm{K}^{+}$and the anions generally showed $\mathrm{HCO}_{3}{ }^{2-}>\mathrm{Cl}^{-}>\mathrm{SO}_{4}{ }^{2-}>\mathrm{NO}_{3}{ }^{-}$.

\subsection{Seasonal variation of ions}

The analytical results show the slightly acidic nature of water in the dry season as $\mathrm{pH}$ ranged from $5.08-6.86$. The waters tended to be slightly acidic to alkaline in the wet season with $\mathrm{pH}$ range of $5.88-8.65$. The $\mathrm{pH}$ values of the dry season fall within the 4.5-7.0 range. This range represents a weak acidic activity, usually that of carbonic acid and smaller amounts of organic acid such as fulvic acid (Langmuir, 1997). Lower $\mathrm{pH}$ values of $(5.08,5.40$ and 5.12) were recorded at locations with high human population density and can be attributed to low buffer capacity of the regolith in such settings (Edet et al, 2005; Edet and Ekpo, 2008). The $\mathrm{pH}$ values however increased markedly in the wet season reflecting the effects of dissolved salts. Sources of such salts may be from weathering of silicates, carbonates, evaporites and sulphide minerals, atmospheric contribution (cyclic salts) as well as anthropogenic inputs (Berner and Berner, 1996).

The electrical conductivity (EC) which expresses ionic strength of solution, varied between $20.9 \mu \mathrm{s} / \mathrm{cm}$ to $622 \mu \mathrm{s} / \mathrm{cm}$ in the dry season and $60-800 \mu \mathrm{s} / \mathrm{cm}$ in the wet season. Statistical analysis of results reveals a minimum average electrical conductivity value of $199 \mu \mathrm{s} / \mathrm{m}$ in the dry season and a high of $243 \mu \mathrm{s} / \mathrm{cm}$ in the wet season. Somewhat high values within the dry season are reflective of increase in ionic strength and could be related to evaporation effects witnessed during this low water level period and aided by an elevated temperature regime in the area.

The water in the massif exhibited low mean values of total dissolved solids (TDS) concentration of $121 \mathrm{ppm}$ in the dry season and $265 \mathrm{ppm}$ in the wet season. The data shows that electrical conductivity and TDS concentration values were lower in the dry season with an increase in the wet season.

An assessment of data shows a general decrease in cation concentration from the dry to wet seasons. Calcium $\left(\mathrm{Ca}^{2+}\right)$ was the most dominant accounting for about $78 \%$ and $61 \%$ of total cation in the dry and wet seasons respectively. Concentration of $\mathrm{Ca}^{2+}$ recorded ranges of $7.27 \mathrm{mg} / \mathrm{l}-135.2 \mathrm{mg} / \mathrm{l}$ in the dry season and $6.04-97.14 \mathrm{mg} / \mathrm{l}$ in the wet season. This dominance of $\mathrm{Ca}^{2+}$ may reflect the process of chemical weathering of silicates and the common occurrence of calcium carbonate (Langmuir, 1997). Water-rock reactions of mineral phases such as plagioclase, calcite, aragonite, anhydrite and dolomite from basement and the sedimentary terrain lying in close proximity to the study area can be adjudged from this.

Sodium $\left(\mathrm{Na}^{+}\right)$was next in dominance with concentration ranges of $1.2-9.0 \mathrm{mg} / \mathrm{l}$ and 1.8 $-7.0 \mathrm{mg} / \mathrm{l}$ in the dry and wet seasons respectively. The lower mean value for $\mathrm{Na}^{+}, 3.98 \mathrm{mg} / \mathrm{l}$ was recorded in the dry season and the higher of $4.35 \mathrm{mg} / \mathrm{l}$ in the wet season.

The other cations, magnesium $\left(\mathrm{Mg}^{2+}\right)$ and potassium $\left(\mathrm{K}^{+}\right)$ranged between $0.4-5.4 \mathrm{mg} / \mathrm{l}$ and $0.5-5.9 \mathrm{mg} / \mathrm{l}$ respectively in the dry season. In the wet season, ranges were $0.3-3.7 \mathrm{mg} / \mathrm{l}$ for $\mathrm{Mg}$ and $0.2-32.18 \mathrm{mg} / \mathrm{l}$ for $\mathrm{K}$. Potassium exhibited the lowest concentration levels relative to other cations. This is common in natural waters due to its tendency to be fixed by clay minerals and precipitate in the formation of secondary minerals (Matthess, 1982). However, $\mathrm{K}^{+}$recorded the highest concentration mean of $13.97 \mathrm{mg} / \mathrm{l}$ next to calcium (23.09 $\mathrm{mg} / \mathrm{l})$ in the wet season. Potassium shows a reverse trend marked by an increase from the dry to wet season. This increase could be attributed to agricultural practice by the use of fertilizers 
for farming by the local populace. Increased surface run-off in the wet season washes these fertilizers, which $\mathrm{K}^{+}$is a major component and subsequently percolates into the sub-surface water reservoirs. However, the decrease in concentration levels of cations in the wet season reflects the impacts of dilution by surface run-off percolating into the sub-surface reservoirs.

Table 1. Descriptive statistics of parameters as measured in the dry season.

\begin{tabular}{|c|c|c|c|c|c|c|c|c|c|c|c|c|c|}
\hline Source & Statistics & $\underset{(\mathrm{C})}{\text { Temp }}$ & pH & $\begin{array}{c}\mathbf{E C} \\
(\mu \mathrm{s} / \mathrm{cm})\end{array}$ & $\begin{array}{c}\text { TDS } \\
(\mathbf{p p n}\end{array}$ & Ca & Mg & $\mathrm{Na}$ & $\mathbf{K}$ & $\mathrm{SO}_{4}$ & $\mathrm{NO}_{3}$ & $\mathrm{HCO}_{3}$ & Cl \\
\hline \multirow{4}{*}{$\begin{array}{c}\text { Ground } \\
\text { water }\end{array}$} & Min & 26.0 & 5.1 & 24.8 & 15.9 & 7.3 & 0.5 & 1.2 & 0.5 & 0.6 & 0.0 & 18.3 & 0.9 \\
\hline & Max & 28.0 & 6.9 & 622.0 & 398.7 & 135.2 & 5.3 & 4.6 & 5.9 & 117.9 & 45.9 & 122.3 & 93.0 \\
\hline & Mean & 27.1 & 6.0 & 300.7 & 180.2 & 39.5 & 3.7 & 3.9 & 3.2 & 40.9 & 15.6 & 45.6 & 23.5 \\
\hline & SD & 0.8 & 0.5 & 255.6 & 169.7 & 43.1 & 1.7 & 0.9 & 1.7 & 32.8 & 15.8 & 29.1 & 28.7 \\
\hline \multirow{4}{*}{$\begin{array}{c}\text { Surface } \\
\text { water }\end{array}$} & Min & 26.0 & 5.1 & 34.6 & 22.2 & 12.3 & 0.4 & 2.0 & 0.8 & 1.1 & 0.0 & 12.3 & 2.5 \\
\hline & Max & 32.0 & 6.3 & 250.0 & 209.0 & 122.1 & 5.4 & 9.0 & 3.5 & 564.1 & 47.5 & 97.6 & 57.0 \\
\hline & Mean & 27.8 & 5.7 & 96.4 & 61.8 & 34.8 & 3.0 & 4.1 & 2.0 & 80.8 & 12.2 & 49.3 & 15.3 \\
\hline & SD & 1.8 & 0.4 & 92.3 & 59.2 & 30.7 & 2.1 & 1.8 & 1.0 & 158.8 & 15.2 & 35.2 & 16.2 \\
\hline $\begin{array}{l}\text { WHO } \\
(2001)\end{array}$ & & & $6.5-8.5$ & 1400 & 1000 & 100 & 50 & 200 & 12 & 400 & 50 & & 250 \\
\hline
\end{tabular}

Table 2. Descriptive statistics of parameters as measured in the wet season.

\begin{tabular}{c|l|r|r|r|r|r|r|r|r|r|r|r|r}
\hline Source & Statistics & $\begin{array}{c}\text { Temp } \\
(\mathbf{(} \mathbf{c})\end{array}$ & $\mathbf{p H}$ & $\begin{array}{c}\mathbf{E C} \\
(\mathbf{\mu s} / \mathbf{c m})\end{array}$ & $\begin{array}{c}\mathbf{T D S} \\
(\mathbf{p p m})\end{array}$ & $\mathbf{C a}$ & $\mathbf{M g}$ & $\mathbf{N a}$ & $\mathbf{K}$ & $\mathbf{S O}_{\mathbf{4}}$ & $\mathbf{N O}_{\mathbf{3}}$ & $\mathbf{H C O}_{\mathbf{3}}$ & $\mathbf{C l}$ \\
\hline & Min & 27.0 & 5.9 & 80.0 & 60.0 & 6.0 & 0.3 & 2.5 & 1.0 & 13.6 & 0.2 & 12.1 & 22.1 \\
$\begin{array}{c}\text { Ground } \\
\text { water }\end{array}$ & Max & 30.0 & 7.7 & 580.0 & 890.0 & 97.1 & 3.4 & 7.0 & 32.2 & 471.7 & 11.7 & 67.0 & 308.7 \\
& Mean & 28.0 & 6.8 & 285.9 & 333.8 & 23.1 & 1.7 & 4.7 & 14.0 & 97.2 & 2.7 & 55.0 & 97.2 \\
& SD & 0.9 & 0.5 & 176.3 & 262.6 & 24.4 & 1.0 & 1.5 & 13.8 & 107.7 & 3.4 & 88.9 & 79.2 \\
\hline & Min & 26.0 & 6.3 & 60 & 40.0 & 7.5 & 0.3 & 1.8 & 0.2 & 25.0 & 0.1 & 24.2 & 50.6 \\
Surface & Max & 30.4 & 8.7 & 430 & 570.0 & 60.1 & 3.7 & 5.7 & 4.7 & 839.6 & 10.0 & 213.5 & 596.6 \\
water & Mean & 28.1 & 7.2 & 200 & 196.2 & 19.5 & 1.5 & 3.9 & 1.8 & 148.6 & 2.6 & 84.9 & 164.5 \\
& SD & 1.1 & 0.7 & 124 & 149.6 & 16.3 & 1.1 & 1.5 & 1.5 & 224.9 & 3.1 & 59.5 & 146.2 \\
\hline $\begin{array}{l}\text { WHO } \\
(\mathbf{2 0 0 1})\end{array}$ & & & $\mathbf{6 . 5 - 8 . 5}$ & $\mathbf{1 4 0 0}$ & $\mathbf{1 0 0 0}$ & $\mathbf{1 0 0}$ & $\mathbf{5 0}$ & $\mathbf{2 0 0}$ & $\mathbf{1 2}$ & $\mathbf{4 0 0}$ & $\mathbf{5 0}$ & & $\mathbf{2 5 0}$ \\
\hline
\end{tabular}

Anion concentration levels generally increased from the dry to the wet seasons. Chloride exhibited a marked increase along this seasonal trend. Sulphate and bicarbonate were the dominant anions within the dry season with mean concentration values of $61 \mathrm{mg} / \mathrm{l}$ and 48 $\mathrm{mg} / \mathrm{l}$ respectively. In the wet season, chloride was most dominant with an average concentration value of $130.5 \mathrm{mg} / \mathrm{l}$. Sulphate had a mean value of $123 \mathrm{mg} / \mathrm{l}$ and bicarbonate, 70 $\mathrm{mg} / \mathrm{l}$. Nitrate was least with mean values of $14 \mathrm{mg} / \mathrm{l}$ and $2.7 \mathrm{mg} / \mathrm{l}$ in the dry and wet seasons respectively.

\subsection{Spatial variations of ions}

Spatial variations for measured parameters across the massif are presented in Table 3. The differences are reflective of degree of regolith development and lithologic characteristics. The western sector of the massif is composed mainly of granodiorites, granites, granitic gneisses and schists and characterized by thick overburden of $29-47 \mathrm{~m}$ as revealed from drilled sections. The eastern sector on the other hand is mainly of migmatites, amphibolites and schists with thinner overburden of $6-12 \mathrm{~m}$. The lineament density, higher for western and 
lower for eastern sectors, as reported by Edet et al., (1994), supports the trend in overburden variability.

Electrical conductivity values across the massif exhibited a lower mean value of 191.42 $\mu \mathrm{s} / \mathrm{cm}$ for the eastern sector and $216.21 \mu \mathrm{s} / \mathrm{cm}$ for the western sector. A lower mean TDS value of $226.9 \mathrm{ppm}$ was recorded for the eastern sector of the massif while a mean value of $296.70 \mathrm{ppm}$ was recorded for the western sector. This shows an increase of TDS and EC from the east to the west of the massif. This is probably due to the depth of the weathered profile as revealed by litho-logs from both sectors and an expected increase of TDS along flow path of groundwater as groundwater flows from the east to west.

The mean value of $\mathrm{pH}$ for the western sector was 6.23 and 6.84 was deduced for the eastern flank. Relatively lower $\mathrm{pH}$ mean value for the western sector may be attributed to sub surface run-off, inputs of organic waste and other anthropogenic inputs due to higher human population density on this flank while higher values for the eastern flank may be due to decrease in dissolved solute (Ekwere, 2010).

The concentration of mobile cations were higher on the western sector of the massif as these are products of mineral dissolution as water flows through the more porous sub-surface media from the eastern to the western sector. Anions Cl-, HCO3- and SO42- however, showed higher mean values on the eastern arm of the massif. This could be attributed to accumulation and concentration of soluble salts in the aquifers as a function of topographic alternation within this axis of the Oban massif (Ekwere, 2010). However, mean values of nitrates were higher on the western sector. This is related to high concentrations of communities and attendant increase in human activity.

Table 3. Mean variations of parameters across western and eastern sectors of the massif.

\begin{tabular}{|c|c|c|}
\hline Parameter & Western Sector & Eastern Sector \\
\hline Temp. $\left({ }^{0} \mathrm{c}\right)$ & 27.7 & 27.9 \\
\hline $\mathbf{p H}$ & 6.2 & 6.8 \\
\hline Conductivity $(\mu \mathrm{s} / \mathrm{cm})$ & 216.2 & 191.4 \\
\hline TDS (ppm) & 296.7 & 226.9 \\
\hline SWL (m) & 2.8 & 3.1 \\
\hline Yield $\left(\mathbf{m}^{3} \mathbf{h r}^{-}\right)$ & 6.1 & 6.2 \\
\hline $\mathbf{C a}$ & 31.7 & 15.6 \\
\hline Mg & 2.7 & 1.5 \\
\hline $\mathbf{N a}$ & 4.3 & 3.6 \\
\hline $\mathbf{K}$ & 6.9 & 1.4 \\
\hline $\mathrm{SO}_{4}$ & 71.6 & 159.9 \\
\hline $\mathrm{NO}_{3}$ & 9.1 & 4.7 \\
\hline $\mathrm{HCO}_{3}$ & 59.4 & 92.4 \\
\hline $\mathbf{C l}$ & 67.1 & 106.6 \\
\hline $\mathrm{PO}_{4}$ & 1.3 & 0.2 \\
\hline $\mathrm{SiO}_{2}$ & 2.0 & 6.9 \\
\hline Lithology & $\begin{array}{l}\text { Gneiss, quartzite, schist, } \\
\text { granodiorite, pegmatite, } \\
\text { gneissic-granite. }\end{array}$ & $\begin{array}{l}\text { Migmatites, schists, } \\
\text { amphibolites, quartzite, } \\
\text { syenites. }\end{array}$ \\
\hline
\end{tabular}




\subsection{Hydrochemical processes controlling water characteristics}

Dissolved species and their relations with each other can reveal the origin of solutes and the processes that generated the observed composition of water. Cross plots and ionic ratios have been used as tools for interpretation of groundwater composition in the study area.

Gibbs (1970) proposed a simple explanation for the general chemistry of both surface and sub-surface waters. He showed that: (1) rainfall (rain dominated), (2) rock-weathering reactions (rock-dominated) and (3) evaporation-crystallization or a combination of these influences, determine the chemistries of surface and ground waters. The plot of TDS against weight ratio of $\mathrm{Na} / \mathrm{Na}+\mathrm{Ca}$ (Figure 2), indicates the mechanisms that determined the major ion composition of sampled waters. Rock dominance appears to be the major controlling factor of the chemistry of sampled waters from the wet season. The plot reveals about $86 \%$ of the sampled waters to be within the rock dominance field. Majority of the waters from the dry season (72\%), plot within the rainfall/precipitation dominance field. This can be explained by effects of evaporation, giving less time for water-rock reactions and dissolution. The waters are of relatively less resident times and their chemistry is of the recharge source (rainfall). The remaining $28 \%$ of the waters plot within the rock dominance field, reflecting some form of structural control leading to higher resident times and effective mineral dissolution processes.

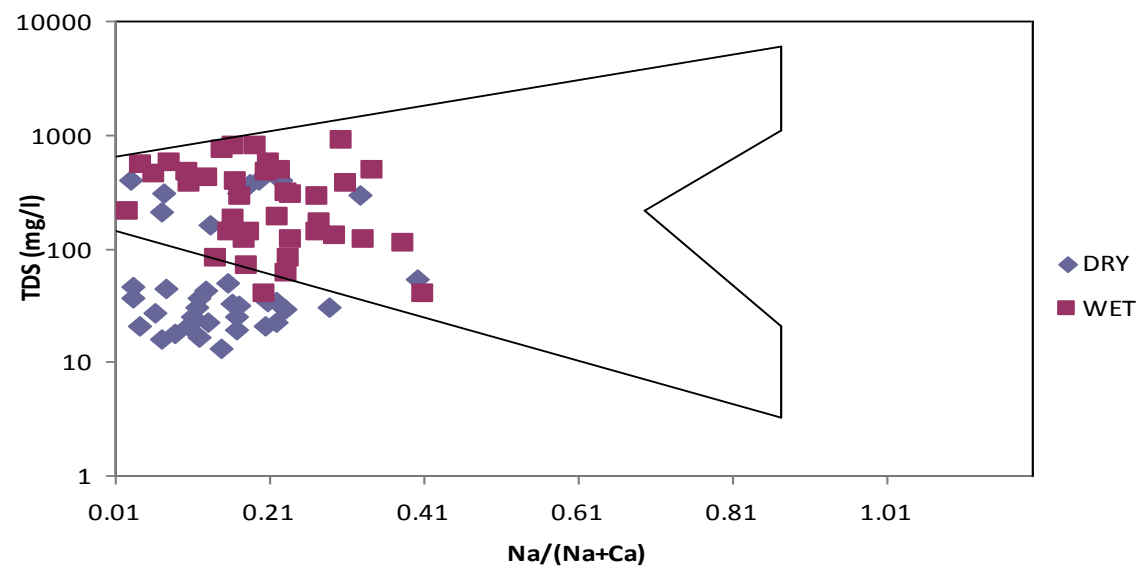

Figure 2. Plot of TDS versus weight ratio of $\mathrm{Na} /(\mathrm{Na}+\mathrm{Ca})$ for sampled waters across seasons.

Plots of $\mathrm{Na}$ versus $\mathrm{Cl}$ have been used to identify the mechanism for acquiring salinity and saline intrusions in aquifers (Zhu et al., 2008; Singh et al., 2005). Generally, evaporation causes an increase in the concentrations of chemical species in water. If the evaporation process is dominant, and no mineral species are precipitated, the $\mathrm{Na}^{+} / \mathrm{Cl}^{-}$ratio is unchanged (Jankowski and Acworth, 1997). Thus, a plot of $\mathrm{Na}^{+} / \mathrm{Cl}^{-}$versus EC would give a horizontal line, which would indicate concentration by evaporation and transpiration (Figure 3a). If simple dissolution of halite is responsible for sodium, then $\mathrm{Na}^{+} / \mathrm{Cl}^{-}$molar ratio would be approximately one. Mean ratios of $\mathrm{Na} / \mathrm{Cl}$ in the dry season was 1.261 and 0.076 for the wet season, Ekwere (2010). Plot of $\mathrm{Na}$ versus $\mathrm{Cl}$ (Figure 3b) shows an excess of $\mathrm{Cl}$ to $\mathrm{Na}$, particularly for samples from shallow and deep aquifers as well as surface waters from the wet season. Most samples of the shallow and deep aquifers also plot below the equiline. Few shallow aquifer and surface water samples from the dry season plot above the equiline reflecting excess of $\mathrm{Na}$ to $\mathrm{Cl}$. The excess of sodium for point plots suggests background levels of $\mathrm{Na}$ that originate from weathering of Na-silicate minerals (e.g. sodium plagioclase) from the crystalline basement. Chloride excess over $\mathrm{Na}^{+}$suggests other sources contributing $\mathrm{Cl}^{+}$to groundwater. A possible source of the excess $\mathrm{Cl}$ in the waters could be saline water from sedimentary rocks adjacent to the crystalline basement. Such saline waters are believed to be 
probably of primitive marine origin (Michard et al., 1996). Ca-Cl water type has been reported from the area, (Ekwere, 2010) and this water type is a result of reverse cation exchange due to the removal of $\mathrm{Na}$ out of solution for bound $\mathrm{Ca}$.

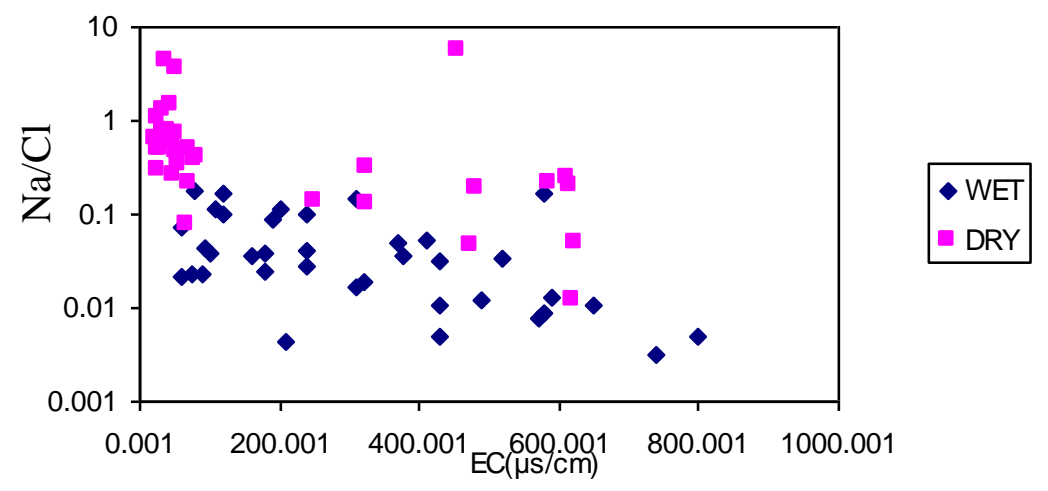

Figure 3a. Plot of $\mathrm{Na} / \mathrm{Cl}$ versus electrical conductivity (EC) for sampled the waters.

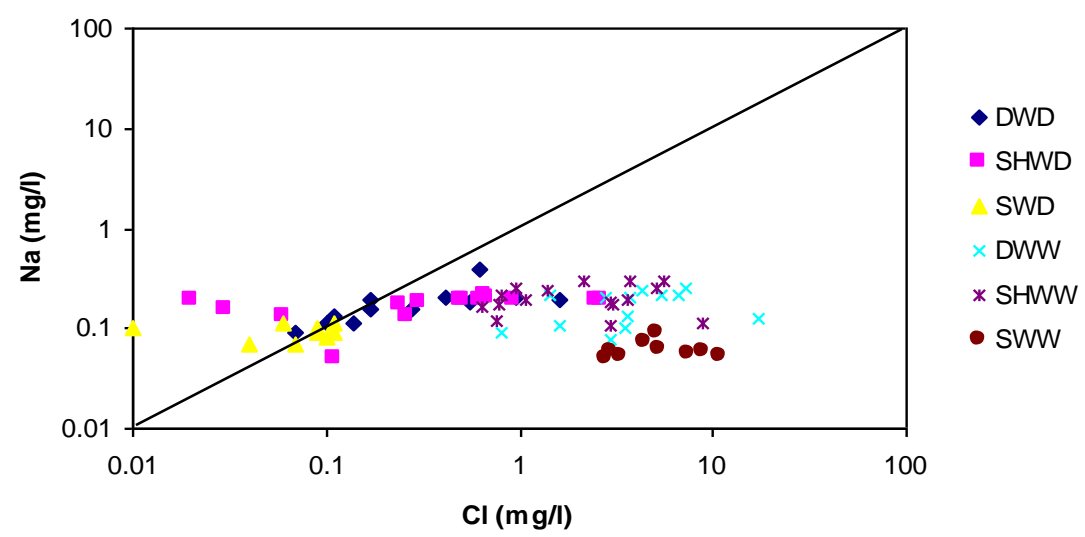

Figure 3b. Plot of $\mathrm{Na}$ versus $\mathrm{Cl}$ for sampled waters.

Note: DWD- deep well dry season; SHWD-shallow well dry season;

SWD-surface water dry season; DWW- deep well wet season;

SHWW- shallow well wet season; SWW- surface water wet season.

$\mathrm{Ca}-\mathrm{Cl}$ type waters could also be a result of the process of mixing between younger, fresher water with more saline older water (Adams et al., 2001). Increased water in aquifers, resultant from recharge levels in the wet season, leads to higher groundwater flow. This supports interaction of water from the adjacent sedimentary terrain with the basement through porous sub-surface media. Another possible source is cation ion exchange processes. Zhu et al. (2008) have shown that low $\mathrm{Na} / \mathrm{Cl}$ ratio of groundwater probably results from ion exchange of $\mathrm{Na}$ for $\mathrm{Ca}$ and $\mathrm{Mg}$ in clay. This is evident in the ratios of these pairs of ionic species from the sampled waters (Ekwere, 2010).

A plot of $\mathrm{Ca}+\mathrm{Mg}$ versus $\mathrm{HCO}_{3}$ (Figure 4) shows that about $81 \%$ of sampled waters plot above the 1:1 equiline, for groundwater from both sampling seasons. This indicates an excess of $\mathrm{Ca}+\mathrm{Mg}$ to $\mathrm{HCO}_{3}$. The remaining fraction, plot around the equiline showing a good correlation between these two factors. This indicates congruent dissolution of silicates (feldspars) and calcite. Surface water samples from the wet season plot below the equiline reflecting excess bicarbonate relative to $\mathrm{Ca}+\mathrm{Mg}$. The excess of $\mathrm{Ca}+\mathrm{Mg}$ over bicarbonate in the waters indicates some extra source of these ions, and a demand that part of these excess 
positive charges has to be balanced by other anions like $\mathrm{SO}_{4}{ }^{2-}$ and/or $\mathrm{Cl}^{-}$. Asides carbonate weathering, silicate weathering (chiefly plagioclase and feldspar), evaporite dissolution can be possible sources of $\mathrm{Ca}^{2+}$ and $\mathrm{Mg}^{2+}$ in water (Ettazarini, 2005; Singh et al., 2005).

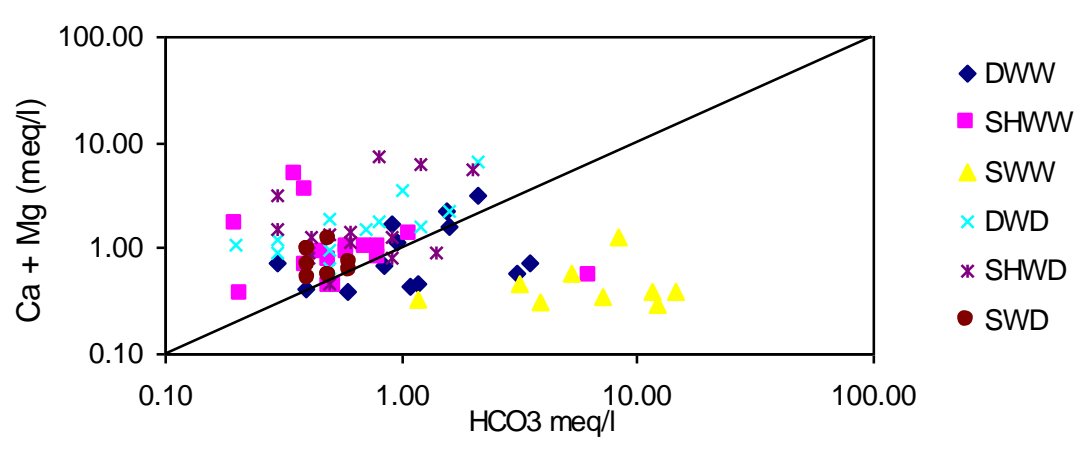

Figure 4. Plot of $\mathrm{Ca}+\mathrm{Mg}$ versus $\mathrm{HCO}_{3}$ for sampled waters across seasons.

The excess of bicarbonate over $\mathrm{Ca}+\mathrm{Mg}$ for samples from the wet season requires that part of the alkalinity should be balanced by alkalis $(\mathrm{Na}+\mathrm{K})$. This bicarbonate excess may be from hydrolysis of carbonate rocks from the Cretaceous sedimentary terrain lying adjacent to the basement complex.

Evidence of silicate weathering and cation exchange can be adjudged by plots of $\mathrm{Ca}+$ $\mathrm{Mg}$ against $\mathrm{HCO}_{3}+\mathrm{SO}_{4}$ (Garcia et al., 2001). This reflects the amount of $\mathrm{Ca}^{2+}$ and $\mathrm{Mg}^{2+}$ gained or lost relative to that provided by the dissolution of $\mathrm{Ca}^{2+}$ and $\mathrm{Mg}^{2+}$ bearing minerals.

Figure 5 shows a plot of this ratio, with most of the points falling below the equiline, a greater percentage being the samples from the wet season. A few samples plot, evolving around the equiline, while a greater percentage of those from the dry season plot above. This demands a portion of the $\mathrm{HCO}_{3}+\mathrm{SO}_{4}$ be balanced by the alkalis $\mathrm{Na}+\mathrm{K}$. Points on and around the equiline correspond to simultaneous calcite and feldspar dissolution. If $\mathrm{Ca}^{2+}, \mathrm{Mg}^{2+}$, $\mathrm{HCO}_{3}{ }^{-}$and $\mathrm{SO}_{4}{ }^{2-}$, were derived from simple dissolution of calcitic minerals and feldspars, then a charge balance should exist between the cations and anions. An ion exchange process is characterized by $\mathrm{HCO}_{3}+\mathrm{SO}_{4}$ excess over $\mathrm{Ca}+\mathrm{Mg}(86 \%$ of the wet season samples and about $17 \%$ of the dry season samples), while the reverse ion exchange is marked by $\mathrm{Ca}+\mathrm{Mg}$ excess over $\mathrm{HCO}_{3}+\mathrm{SO}_{4}$, largely for the dry season samples (Cerling et al., 1989; Fisher and Mullican, 1997; Ettazarini, 2005).

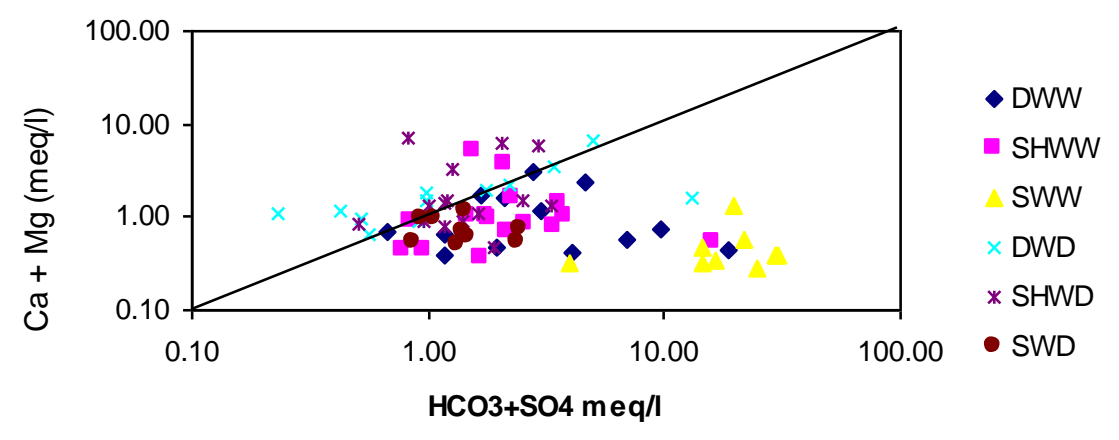

Figure 5. Plot of $\mathrm{Ca}+\mathrm{Mg}$ versus $\mathrm{HCO}_{3}+\mathrm{SO}_{4}$ for sampled waters across seasons. 
A plot of $(\mathrm{Ca}+\mathrm{Mg})$ versus TC (total cation) for samples from both seasons shows that all the points plot along and close to the equiline in a linear spread, Figure 6a. The average ratio of $[\mathrm{Ca}+\mathrm{Mg}] / \mathrm{TC}$ were 0.86 and 0.76 for the dry and wet seasons respectively. Plot of $\mathrm{Na}+\mathrm{K}$ against TC (Figure 6b) shows that, all points plot below the equiline for both seasons. The average ratios of $(\mathrm{Na}+\mathrm{K}) / \mathrm{TC}$ are 0.14 and 0.24 for the dry and wet seasons respectively. Calcium and magnesium are the dominant cations across seasons. Evaporation and $\mathrm{Ca}^{2+}$ precipitation alongside $\mathrm{Mg}^{2+}$ is responsible for the dominance of these ionic species in the dry season (Ekwere, 2010). The degree of dominance however decreases from the dry to the wet seasons. The ratio of $\mathrm{Na}+\mathrm{K}$ to $\mathrm{TC}$ increases from the dry to the wet seasons. This indicates an increasing contribution of alkalis with increase in dissolved solids (Singh et al., 2005).

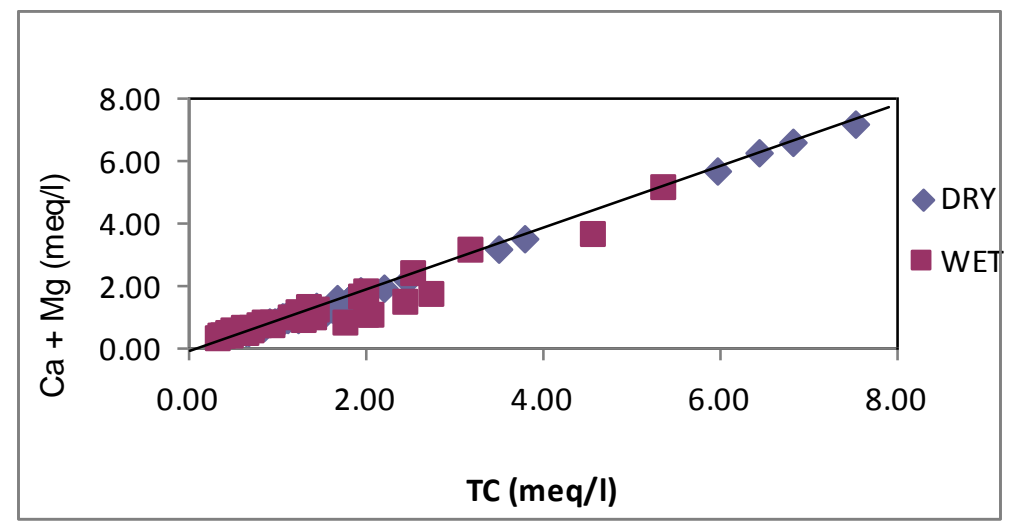

Figure 6a. Plot of $\mathrm{Ca}+\mathrm{Mg}$ versus total cation (TC) sampled waters across seasons.

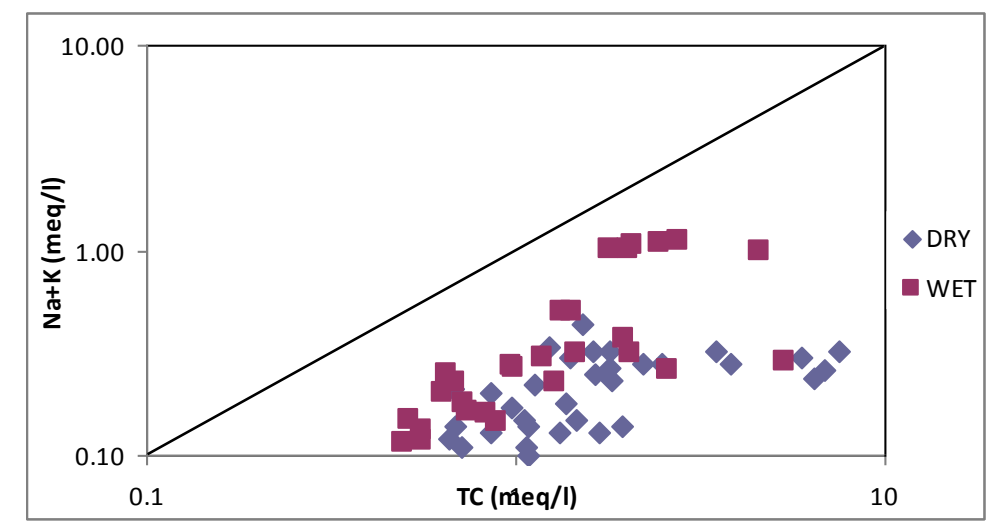

Figure 6b. Plot of $\mathrm{Na}+\mathrm{K}$ versus total cation (TC) for sampled waters across seasons.

\subsection{Factor analysis}

Factor analysis is a multivariate statistical technique that is widely used to aid interpretation of geochemical data and enhances subtle but significant single-element anomalies (Garret and Nichol, 1969). In other words, factor analysis has the simple objective of revealing an underlying relation that is presumed to exist within a set of multivariate observation, (Davies, 1986). By so doing, the structure of the underlying system that produced the data is well understood. Factor analyses were employed in this study to process data and determine the sources of incipient ionic species relative to physical parameters as well as factors controlling such. Results of R- mode factor analyses for both seasons of sampling are summarized in factor matrix Tables 4 and 5. 
EKWERE, A. S.; EDET, A. E.; EKWERE, S. J. Groundwater chemistry of the Oban Massif, South-Eastern Nigeria. Ambi-Agua, Taubaté, v. 7, n. 1, p. 51-66, 2012. (http://dx.doi.org/10.4136/ambi-agua.812)

Table 4. Factor loading for dry season.

\begin{tabular}{|c|c|c|c|c|}
\hline \multicolumn{5}{|c|}{ FACTOR } \\
\hline Variables & 1 & 2 & 3 & 4 \\
\hline Temp. & -0.004 & 0.020 & -0.034 & -0.927 \\
\hline EC & 0.944 & -0.036 & 0.030 & -0.046 \\
\hline TDS & 0.944 & -0.036 & 0.030 & -0.046 \\
\hline pH & -0.458 & 0.117 & -0.401 & 0.298 \\
\hline $\mathbf{N a}$ & 0.573 & 0.184 & 0.382 & 0.231 \\
\hline $\mathbf{K}$ & 0.806 & 0.425 & 0.042 & 0.050 \\
\hline $\mathbf{C a}$ & 0.233 & 0.824 & 0.052 & 0.096 \\
\hline Mg & 0.767 & 0.576 & 0.079 & 0.153 \\
\hline Cl & 0.584 & 0.211 & 0.436 & 0.203 \\
\hline $\mathrm{HCO}_{3}{ }^{-}$ & -0.001 & 0.921 & 0.144 & -0.086 \\
\hline $\mathrm{SO}_{4}{ }^{2-}$ & -0.131 & 0.105 & 0.877 & -0.083 \\
\hline $\mathrm{NO}_{3}{ }^{-}$ & 0.332 & 0.147 & 0.734 & 0.227 \\
\hline Eigenval & 4.949 & 1.704 & 1.390 & 1.088 \\
\hline$\%$ Variance & 41.242 & 14.198 & 11.586 & 9.064 \\
\hline Cumul. Eigenv. & 4.949 & 6.653 & 8.043 & 9.131 \\
\hline \% Cumul. & 41.242 & 55.440 & 67.026 & 76.090 \\
\hline
\end{tabular}

On inspection, a four and three factor models were recognized for the dry and wet seasons respectively. Only variables with loadings greater than 0.50 , were considered significant members of a particular factor.

In the dry season, factor one (EC, TDS, $\mathrm{Na}, \mathrm{K}, \mathrm{Mg}$ and $\mathrm{Cl}$ ) accounted for $41.2 \%$ of total data variance and was interpreted as related to geogenic processes; infiltration of surface runoff and other sub-surface fluids, dissolution processes, mixing of waters and cation exchange processes.

The second factor $\left(\mathrm{Ca}, \mathrm{Mg}, \mathrm{HCO}_{3}\right)$, with $14.2 \%$ data variance, was interpreted to be related to natural weathering of $\mathrm{Ca}$ and $\mathrm{Mg}$ bearing minerals and lesser extents of carbonate dissolution processes within the porous sub-surface media. The main cation exchange elements $\mathrm{Ca}^{2+}$ and $\mathrm{Mg}^{2+}$ relative to $\mathrm{HCO}_{3}{ }^{-}$correlated positively indicating the influence of the geological matrix.

Factor $3\left(\mathrm{SO}_{4}\right.$ and $\left.\mathrm{NO}_{3}\right)$ accounted for $11.6 \%$ data variance and was interpreted to be reflective of biogenic reactions. Organic activities within the soil profile affects infiltrating water, Langmuir (1997). Impacts of land use practices could also be inferred due to the presence of the biochemical $\mathrm{NO}_{3}$, which is a principal plant nutrient (Adams et al, 2001). The fourth factor, which is temperature, shows its effects on the series of processes that control the chemistry of sampled waters.

Results from R-mode factor analysis for the wet season shows factor $1(\mathrm{Na}, \mathrm{K}, \mathrm{Ca}$ and $\mathrm{Mg}$ ) accounts for $36.2 \%$ of data variation, reflecting natural weathering from water-rock interactions in geo-matrix of the basement. Factor 2, (EC, TDS, $\mathrm{HCO}_{3}, \mathrm{SO}_{4}$ ), exhibits loading that accounts for about $18.9 \%$ of data variance. This factor is believed to be related to 
weathering and water-rock reactions. Inputs of mobile phases of ionic species $\left(\mathrm{SO}_{4}{ }^{2-}\right.$ and $\left.\mathrm{HCO}_{3}{ }^{-}\right)$from dissolution and cation exchange are evident in conductivity levels. Factor $3(\mathrm{pH}$, $\mathrm{NO}_{3}$ ) accounts for $11.7 \%$ of data variance and similar to factor three of the dry season, it indicates the effects of organic activities controlled by varying $\mathrm{pH}$ conditions as well as effects of land use practices.

\subsection{Chemical types and trends of groundwater}

In order to ascertain the groundwater types and visualize the trends of chemistry, the Piper trilinear diagram was used (Figures $7 \mathrm{a}$ and $7 \mathrm{~b}$ ). These show the relative concentrations of the different ionic species for the individual sample type based on average values across the sampling seasons. Calcium is the dominant cation across both seasons. Bicarbonate is the dominant anion for the water types in the wet season, while chloride is for the dry season. The recognizable water types are; $\mathrm{Ca}-(\mathrm{Mg})-\mathrm{HCO}_{3}$ and $\mathrm{Ca}-(\mathrm{Na})-\mathrm{Cl}-\mathrm{SO}_{4}$.

The $\mathrm{Ca}-(\mathrm{Mg})-\mathrm{HCO}_{3}$ water type is defined as the normal alkaline group of water. Amadi (1987) describes this type of water of being typical of Nigerian basement terrain with limited mixing, perhaps reflecting a primary stage of evolution of its groundwater system. Similar water type has been reported for the western basement complex of Nigeria by Elueze et al. (2004) and Tijani (1994). The chemical composition of this water type is said to be due to the dissolution of silicate minerals in the bedrock and aluminosilicates in the weathered regolith, Tijani (1994).

The $\mathrm{Ca}-\mathrm{Na}-\mathrm{Cl}-\mathrm{SO}_{4}$ association is defined as a major constituent of atmospheric precipitation (Davis and De Weist, 1966). Elueze et al. (2004) reports occurrence of such water type in the western sector of the Nigerian basement complex. The chemistry of this water type is therefore influenced by precipitation.

Table 5. Factor loading for wet season.

\begin{tabular}{|c|c|c|c|}
\hline \multicolumn{4}{|c|}{ FACTOR } \\
\hline VARIABLE & 1 & 2 & 3 \\
\hline Temp. & 0.405 & -0.385 & -0.207 \\
\hline EC & -0.135 & 0.945 & 0.072 \\
\hline TDS & 0.132 & 0.884 & -0.125 \\
\hline $\mathbf{p H}$ & -0.285 & -0.221 & 0.821 \\
\hline $\mathbf{N a}$ & 0.849 & -0.278 & -0.117 \\
\hline $\mathbf{K}$ & 0730 & -0.040 & 0.071 \\
\hline $\mathbf{C a}$ & 0.631 & 0.164 & -0.009 \\
\hline Mg & 0.879 & -0.035 & -0.028 \\
\hline Cl & -0.124 & 0.447 & 0.137 \\
\hline $\mathrm{HCO}_{3}^{-}$ & -0.500 & 0.691 & 0.154 \\
\hline $\mathrm{SO}_{4}{ }^{2-}$ & -0.499 & 0.591 & 0.462 \\
\hline $\mathrm{NO}_{3}{ }^{-}$ & 0.254 & 0.301 & 0.792 \\
\hline Eigenval & 4.339 & 2.272 & 1.409 \\
\hline$\%$ Variance & 36.155 & 18.934 & 11.742 \\
\hline Cumul. Eigenv. & 4.339 & 6.611 & 8.020 \\
\hline \% Cumul. & 36.155 & 55.089 & 66.831 \\
\hline
\end{tabular}


EKWERE, A. S.; EDET, A. E.; EKWERE, S. J. Groundwater chemistry of the Oban Massif, South-Eastern Nigeria. Ambi-Agua, Taubaté, v. 7, n. 1, p. 51-66, 2012. (http://dx.doi.org/10.4136/ambi-agua.812)

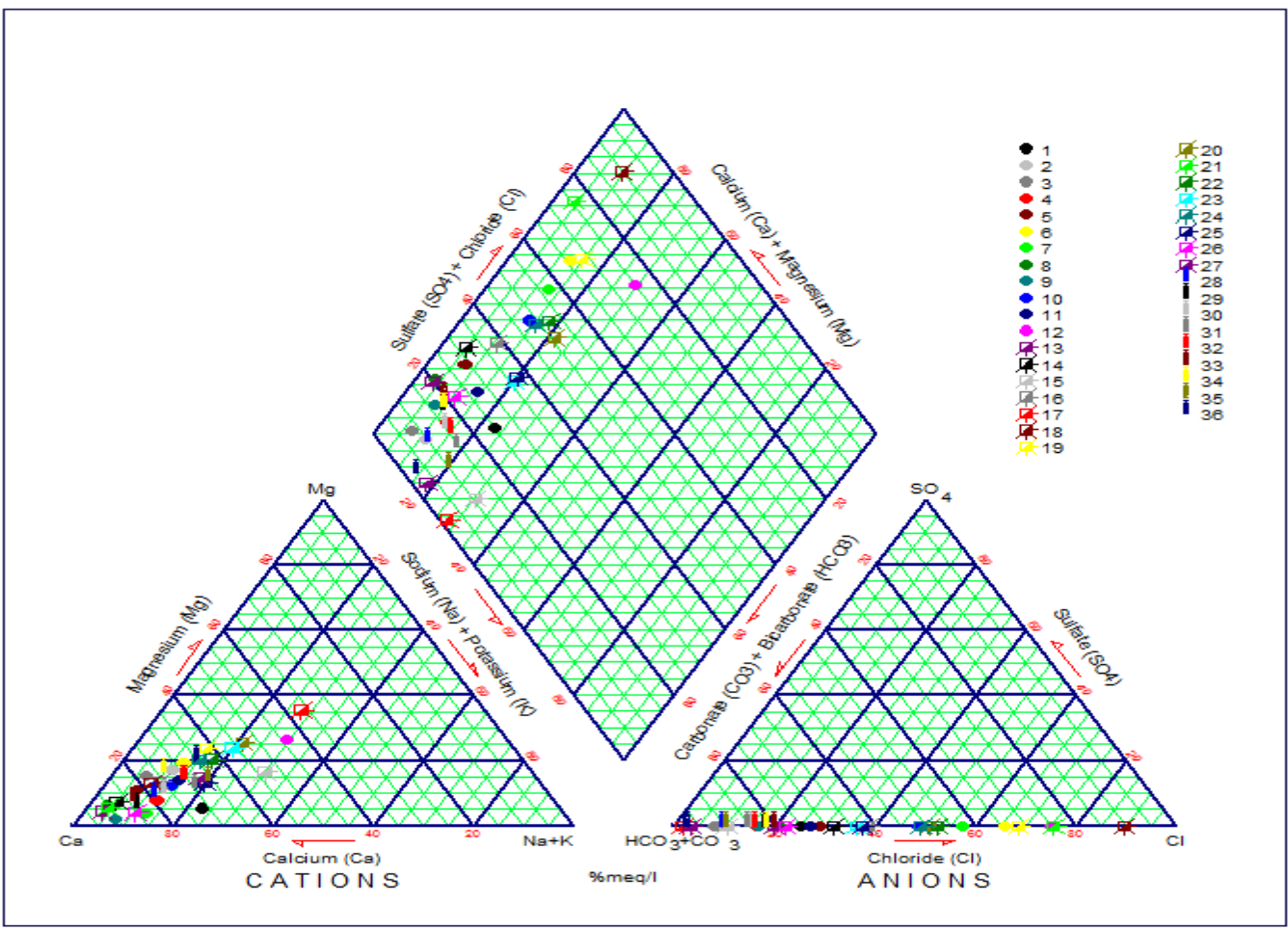

1-12 boreholes; 13-27 open wells; 28-36 surface streams

Figure 7a. Trilinear diagram plot of water samples from the dry season.

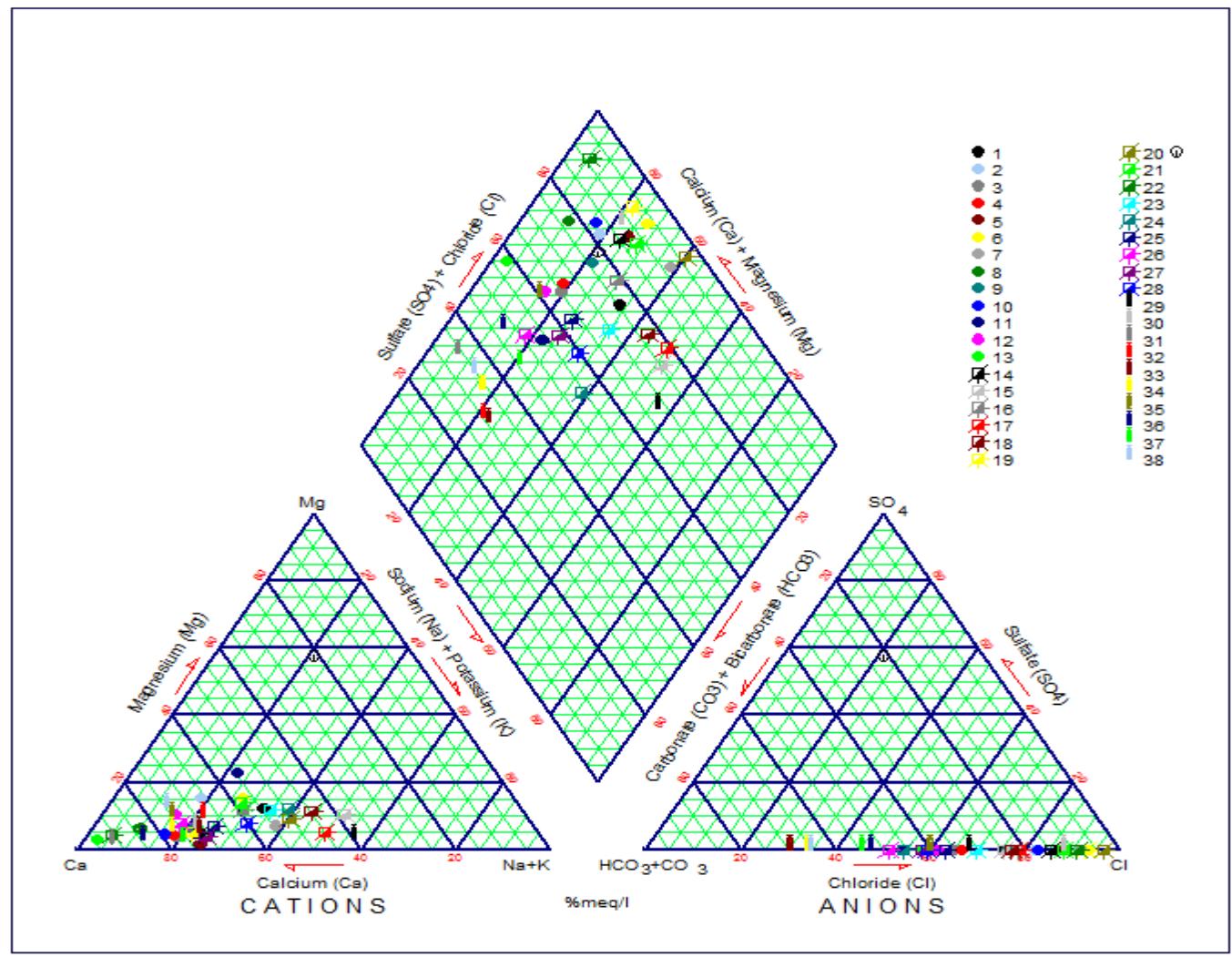

1-13 boreholes; $14-28$ open wells; 29-38 surface streams

Figure 7b. Trilinear diagram plot of water samples from the wet season. 


\section{CONCLUSIONS}

The present hydrochemical status of the study area shows concentration levels of ionic species to be controlled by geogenic processes. Geologic and hydrogeologic features affect the chemistries as exhibited by groundwater. Order of abundance of major chemical species was $\mathrm{Ca}>\mathrm{Na}>\mathrm{Mg}>\mathrm{K}$ and $\mathrm{HCO}_{3}>\mathrm{SO}_{4}>\mathrm{Cl}$ with minor spatial variations across the sampling seasons. Deductions from ionic ratios cross plots and factor analysis support interrelations between ionic species that can be explained by geologic processes. These adjudged natural processes include weathering of mineral phases (mainly silicates), water mixing (from adjacent sedimentary terrain), and ion exchange reactions. This broad spectrum of hydrochemical dynamics is indicated by two dominant hydrochemical facies; $\mathrm{Ca}-(\mathrm{Na})-\mathrm{Cl}-\mathrm{SO}_{4}$ and $\mathrm{Ca}-(\mathrm{Mg})-\mathrm{HCO}_{3}$ water types in the study area.

\section{REFERENCE}

ADAMS, S. S.; TITUS, R.; PIETERSEN, K.; TREDOUX, G.; HARRIS, C. Hydrochemical characteristics of aquifers near Sutherland in Western Karoo, South Africa. Journal of Hydrology, v. 241, p. 91-103, 2001 http://dx.doi.org/10.1016/S0022-1694(00)00370-X

AMERICAN PUBLIC HEALTH ASSOCIATION - APHA. Standard methods for the examination of water and wastewater. $19^{\text {th }}$ ed. Washington, 1995.

AYI, N. E. Geology and geochemistry of the eastern part of the Oban massif. 1987. Thesis (M.Sc in Geology) - Dept. of Geology, University of Calabar, Calabar, 1987.

BERNER, E. K.; BERNER, R. A. Global environment: water, air and geochemical cycles. Upper Saddle River: Prentice Hall, 1996.

CARITAT, P. de; KIRSTE, D.; CARR, G.; McCULLOCH, M. Groundwater in Broken Hill region, Australia: recognizing interaction with bedrock and mineralization using $\mathrm{S}, \mathrm{Sr}$ and Pb isotopes. Applied Geochemistry, v. 20, p. 767-787, 2004.

http://dx.doi.org/10.1016/j.apgeochem.2004.11.003

CERLING, T. E.; PEDERSON, B. L.; DAMM, K. L. V. Sodium-Calcium ion exchange in the weathering shales. Implications for global weathering budgets. Geology, v. 17, p. 552554, 1989. http://dx.doi.org/10.1130/0091-7613(1989)017<0552:SCIEIT>2.3.CO;2

CROSS RIVER BASIN DEVELOPMENT AUTHORITY - CRBDA. Hydrogeological survey of lower Cross River Basin: final report. Calabar, 2008. 158p.

DAVIS, S. N.; De WEIST, R. J. M. Hydrogeology. New York: John Wiley \& Sons, 1966.

DAVIES, J. C. Statistics and data analysis in geology. $2^{\text {nd }}$ ed. New York: Wiley and Sons, 1986.

EDET, A. E.; TEME, S. C.; OKEREKE, C. S.; ESU, E. O. Linearment analysis for groundwater exploration in Precambrian Oban massif and Obudu Plateau, SE Nigeria. Journal of Mining and Geology, v. 30, n. 1, p. 8-95, 1994.

EDET, A. E.; OKEREKE, C. S.; TEME, S. C.; ESU, E. O. Application of remote-sensing data to groundwater exploration: a case study of the Cross River State, SE Nigeria. Hydrogeology Journal, v. 6, p. 394-404, 1998.

http://dx.doi.org/10.1007/s100400050162 
EDET, A. E.; OKEREKE, C. S. Hydrogeological and hydrochemical character of the regolith aquifer, northern Obudu Plateau, Southern Nigeria. Hydrogeology Journal, v. 13, p. 391-415, 2005. http://dx.doi.org/10.1007/s10040-004-0358-9

EDET, A. E.; EKPO, B. O. Hydrogeochemistry of a fractured aquifer in the Ogoja/Obudu area of SE Nigeria. In: ADELANA, S.; MacDONALD, A. Applied groundwater studies in Africa. Boca Raton: Taylor and Francis, 2008. p. 391-403. (Selected Papers on Hydrogeology, 13)

EKWERE, S. J.; EKWUEME, B. N. Geochemistry of precambrian gneisses in the eastern part of the Oban massif, southeastern Nigeria. Geolgie en Mijnbouw, v. 70, p. 105-114, 1991.

EKWERE, A. S. Hydrogeological and hydrogeochemical framework of the Oban Massif, south-eastern Nigeria. 2010. Thesis (Ph.D.) - Dept. of Geology, University of Calabar, Calabar, 2010.

EKWUEME, B. N. Rb-Sr ages and petrologic features of Precambrian rocks from the Oban massif, south-eastern Nigeria. Precambian Research, v. 47, p. 271-286, 1990. http://dx.doi.org/10.1016/0301-9268(90)90042-O

EKWUEME, B. N. The Precambrian geology and evolution of the Southeastern Nigerian basement complex. University of Calabar Press 135p, 2003.

EKWUEME, B. N.; EKWERE, S. J. The geology of the eastern sector of Oban massif, southeastern Nigeria. Journal Mining and Geology, v. 25, n. 1/2, p. 317-329, 1989.

ELUEZE, A. A.; OMIDIRAN, J. O.; NTON, M. E. Hydrogeochemical investigation of surface water and groundwater around Ibokun, Ilesha area, southwestern Nigeria. Journal Mining and Geology, v. 40, n. 1, p. 57-64, 2004.

ETTAZARINI, S. Processes of water-rock interaction in the Turonian aquifer of Oum ErRabia Basin, Morocco. Environmental Geology, v. 49, p. 293-299, 2005. http://dx.doi.org/10.1007/s00254-005-0088-x

FISHER, R. S.; MULLICAN, W. F. Hydrochemical evolution of sodium-sulfate and sodiumchloride groundwater beneath the Northern Chihuahua Desert, Trans-Pecos, Texas, USA. Hydrogeology Journal, v. 5, n. 2, p. 4-16, 1997. http://dx.doi.org/10.1007/s100400050102

GARCIA, M. G.; HIDALGO, M. V.; BLESA, M. A. Geochemistry of groundwater in the alluvial plain of Tucuman province, Argentina. Hydrogeology Journal v. 9, p. 597 610, 2001. http://dx.doi.org/10.1007/s10040-001-0166-4

GARRET, R. G.; NICHOL, I. Factor analysis as an aid in the interpretation of regional geochemical streams sediment data. Golden: Colorado School of Mines, 1969. p. 245264.

GIBBS, R. J. Mechanism controlling world water chemistry. Science, v. 170, n. 10, p. 88- 90, 1970.

JANKOWSKI, J.; ACWORTH, R. I. Impact of debris-flow deposits on hydrogeochemical processes and the development of dry land salinity in the Yass River catchment, New South Wales, Australia. Hydrogeology Journal, v. 5, n. 4, p. 71-88, 1997. http://dx.doi.org/10.1007/s100400050119 
LANGMUIR, D. Aqueous environmental geochemistry. Upper Saddle River: Prentice Hall, 1997.

MATTHESS, G. The properties of groundwater. New York: Wiley, 1982.

MICHARD, G.; PEARSON JR., F. J.; GAUTSCHI, A. Chemical evolution of waters during long term interaction with granitic rocks in Northern Switzerland. Applied Geochemistry, v. 11, p. 757-774, 1996. http://dx.doi.org/10.1016/S0883-2927(96)00014-5

OELKERS, E. H. Physical and chemical properties of rock and fluids for chemical mass transport calculation. Reviews in Mineralogy and Geochemistry, v. 34, p. 131-191, 1996.

SINGH, A. K.; MONDAL, G. C.; SINGH, P. K.; SINGH, S.; SINGH, T. B.; TEWARY, B. K. Hydrochemistry of reservoirs of Damodar River Basin, India: weathering processes and water quality assessment. Environmental Geology, v. 48, p. 1014-1028, 2005. http://dx.doi.org/10.1007/s00254-005-1302-6

TIJANI, M. N. Hydrochemical assessment of groundwater in Moro area, Kwara State, Nigeria. Environ. Geol. Vol 24. pp. 194 - 202, 1994. http://dx.doi.org/10.1007/BF00766889

ZHU, G. F.; SU, Y. H.; FENG, Q. The hydrochemical characteristics and evolution of groundwater and surface water in the Heihe River Basin, northwest China. Hydrogeology Journal, v. 16, p. 167-182, 2008. http://dx.doi.org/10.1007/s10040-007-0216-7 